THE CALIPHATE OF MAN 



\title{
THE CALIPHATE OF MAN
}

\author{
Popular Sovereignty \\ in Modern Islamic Thought
}

Andrew F. March

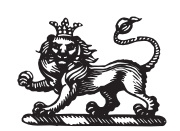

The Belknap Press of

Harvard University Press

Cambridge, Massachusetts / London, England / 2019 
Copyright (C) 2019 by the President and Fellows of Harvard College All rights reserved Printed in the United States of America

First printing Jacket art: DamienGeso/iStock/Getty Images Plus Jacket design: Jill Breitbarth

9780674242746 (EPUB)

9780674242753 (MOBI)

9780674242739 (PDF)

The Library of Congress has cataloged the printed edition as follows:

Names: March, Andrew F., 1976- author.

Title: The caliphate of man : popular sovereignty in modern Islamic thought / Andrew F. March.

Description: Cambridge, Massachusetts : The Belknap Press, Harvard University Press, 2019. | Includes bibliographical references and index. Identifiers: LCCN 2019010887 | ISBN 9780674987838 (alk. paper)

Subjects: LCSH: Islam and politics. | Islam and state. | Ummah (Islam) | Caliphate. | Islamic fundamentalism. | Islamic countries-Politics and government.

Classification: LCC BP173.7 .M3769 2019 | DDC 320.55/7-dc23 LC record available at https://lccn.loc.gov/2019010887 
To Tamir and Ayla 
